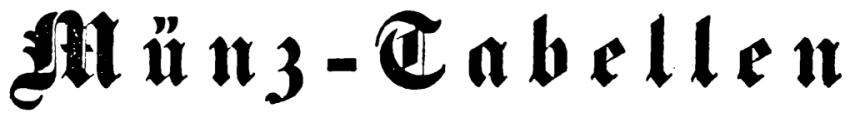

für

\section{Nelfenbredyerzz $\mathfrak{I}$ a(d)enbud}

(

Bon

S. C. Ranbelbard,

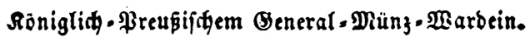

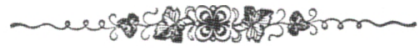

$\mathfrak{B} \mathfrak{e} \mathfrak{r} \mathfrak{i} \mathfrak{n}, 1848$.

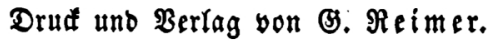


